\title{
Ageing population of voters backs Alzheimer's funding
}

[WASHINGTON] Groups intent on securing increases in US research funding for particular diseases have recently intensified campaigns in Washington DC in the hope of substantially increasing their shares of the generous 1999 budget increase proposed for the National Institutes of Health (NIH).

Many have been using well-known personalities to present their case, and are

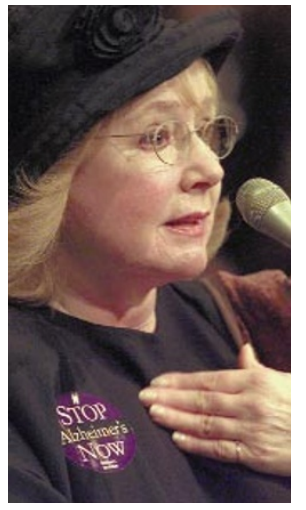

countering warnings from the scientific community that such lobbying distorts research priorities with appeals both to scientific opportunity and to the economic incentives to target diseases that will affect increasingly large numbers of an ageing population.

Actress Piper Laurie The Alzheimer's at last week's hearing. Association, for example, wants an extra $\$ 100$ million - a 28.6 per cent increase - in funding for the disease. This was the subject of a hearing convened by Senator Arlen Specter (Republican, Pennsylvania) last week which featured, among others, the actress Piper Laurie. Specter chairs the subcommittee that writes the bill that funds NIH.

Similarly, advocates for people with Parkinson's disease — including former heavyweight boxer Muhammad Ali, who suffers from the disease - made their case to the health and environment subcommittee of the House of Representatives Commerce Committee, which writes occasional bills setting the broad direction for NIH.

They insisted that doubling the funding for research into Parkinson's disease is essential for adequately exploiting research opportunities. They also argued that Congress is legally bound to produce the funds under a law passed last year calling for $\$ 100$ million in new Parkinson's money over each of the next three years, as it had not provided the money (see Nature 389, 112; 1997).

The flurry of lobbying comes as Congress sets about drafting spending bills that promise to give the NIH an increase of at least 8.4 per cent, to $\$ 14.8$ billion, and perhaps even more. It also comes on the heels of strong objections from NIH directors to congressional interference in research funding.

The directors told a panel convened by the Institute of Medicine last month that efforts by Congress to "earmark" funds for specific diseases "deform" science and, when perma- nent, are even "lethal" to the research enterprise (see Nature 392, 116; 1998).

Such pleas, however, do not always prevail with politicians who may draw on personal experience of family or friends crippled by diseases. For instance, Paul Wellstone (Democrat, Minnesota), a leading backer of increased Parkinson's funding, saw both his parents suffer with the disease.

And Newt Gingrich, the Speaker of the House of Representatives, whose mother-inlaw has diabetes, wrote a $\$ 150$ million increase in spending on juvenile diabetes research into the balanced budget law last year (see Nature 388, 617; 1997)

Richard Hodes, the director of the National Institute on Aging, which funds about three-quarters of NIH Alzheimer's research, says the new money could "very definitely" be spent on first-rate science, and that the ageing of the US population presents a "time imperative" for accelerating the research. Steven Hyman, director of the National Institute of Mental Health, which plans to spend \$28 million on Alzheimer's in 1999, says the field has "immense opportunity".

But both men argue against the Alzheimer's Association's attempts to increase research spending by 28.6 per cent. (The budget that President Bill Clinton sent to the Congress in February would increase it by 7.4 per cent, to $\$ 375$ million.)

Hodes says that "scientific planning and scientific resource setting", not Congress, should determine how the NIH spends its money. And Hyman argues that if Congress were to allocate an extra $\$ 100$ million for Alzheimer's without increasing the entire $\mathrm{NIH}$ budget by the same amount, it would force the NIH to raid accounts for other diseases, and "might actually draw money from better to less worthy science".

But in a country where 14 million people are expected to succumb to Alzheimer's when the baby boomers reach 65, politicians are hard pressed to resist calls to target a costly disease. At last week's hearing, Specter said the Alzheimer's Association's goal of $\$ 100$ million in new funding this year is "laudable". And Tom Harkin (Democrat, Iowa), the senior Democrat on the subcommittee, urged advocates to put "maximum" pressure on Congress to vote for the increased Alzheimer's spending.

At the House of Representatives, the reaction from John Porter (Republican, Illinois), the chairman of the subcommittee that funds the $\mathrm{NIH}$, was less encouraging. Porter said that, where the NIH was concerned, political judgement was no substitute for scientific judgement.

\section{Coalition to pursue ethnic concerns over gene research}

[COLLEGE PARK, MARYLAND] The concerns of ethnic minorities about genetics research and related policies are to be addressed by a coalition of US academics, clinicians and community advocates. The coalition, which argues that the interests of a substantial proportion of the US population are frequently overlooked by genome researchers, has promised to provide a focus for these concerns.

The multicultural task force was set up last week at the end of a two-day symposium on genetics and ethnic minorities sponsored by Howard University in Washington DC and the Sinai Hospital in Baltimore, Maryland. The organizer, Ilana Mittman, who is director of the genetic counselling programme at Howard, a historically black college, said at the symposium: "The interests of communities of colour must be tied to the design and implementation of genetic policy."

Mittman said that the new group plans to link up with the American Association for the Advancement of Science to organize legislative hearings. The group would press Congress to link funding for genome research to performance in this area. Informed consent, institutional review boards and possible bias in research design, scientific review and funding would all come under scrutiny, she said.

Patricia King, law professor at Georgetown University in Washington DC, said: “The conceptual framework doesn't work any more." She argued that existing structures, such as institutional review boards, broadbased recruitment and informed consent, had each failed to provide sufficient protection for minorities. Researchers needed to find ways of ensuring that those who contribute to research are also able to benefit.

Genome-project administrators at the meeting acknowledged there is work to be done. "I'm here to listen and learn; I would be first to say we're not doing enough," said Dan Drell, who oversees research in the ethical, legal and social implications (ELSI) aspects of the human genome programme for the Department of Energy.

Participants argued that definitions and initiatives developed solely from the perspective of white Americans risked diverting attention from some urgent needs of nonwhites. For example, they complained about the decision to offer cystic fibrosis screening to all pregnant women, pointing out that African-Americans, Asian-Americans and Latinos are very unlikely to be carriers.

There was also criticism of researchers for lumping together ethnic groups into broad categories such as Asian-Americans and Hispanics, masking health problems particular to certain subgroups.
Sally Lehrman 